\title{
Pre-prosthetic surgery of alveolar part of the mandible using thermoformed surgical template
}

\author{
Przedprotetyczny zabieg chirurgicznej plastyki części zębodołowej \\ żuchwy z wykorzystaniem szablonu chirurgicznego wykonanego metodą \\ termoformowania
}

\author{
Marcin Szerszeń $^{1}$, Marcin Adamiec ${ }^{2}$, Katarzyna Krzeszowiak ${ }^{3}$ \\ ${ }^{1}$ Katedra Protetyki Stomatologicznej, Warszawski Uniwersytet Medyczny \\ Chair of Prosthodontics, Medical University of Warsaw \\ Head: prof. dr hab. n. med. Elżbieta Mierzwińska-Nastalska \\ ${ }^{2}$ Zakład Chirurgii Stomatologicznej, Warszawski Uniwersytet Medyczny \\ Oral Surgery Department, Medical University of Warsaw \\ Head: prof. dr hab. n. med. Andrzej Wojtowicz \\ ${ }^{3}$ Studenckie Koło Naukowe, Katedra Protetyki Stomatologicznej, Warszawski Uniwersytet Medyczny \\ Students' Research Group, Medical University of Warsaw
}

KEY WORDS:

pre-prosthetic surgery, thermoforming, surgical template

\section{Summary}

Appropriate preparation of the patient's oral cavity for planned prosthetic treatment is an obligatory procedure, which often focuses on improving the quality of the prosthetic base. Depending on the case, it is sometimes necessary to make additional devices used when preprosthetic surgical procedures are performed. This study describes the case of a patient who underwent osteogingivoplasty and frenulotomy, whose healing period was supported with a softhard surgical plate made with thermoforming techniques.
HASŁA INDEKSOWE:

chirurgia przedprotetyczna, termoformowanie, płytka chirurgiczna

\footnotetext{
Streszczenie

Odpowiednie przygotowanie jamy ustnej pacjenta do planowanego leczenia protetycznego jest postepowaniem obligatoryjnym i skoncentrowane jest na polepszeniu jakości pola protetycznego. W zależności od przypadku, niekiedy konieczne jest wykonanie dodatkowych aparatów wykorzystywanych $w$ procesie przedprotetycznych zabiegów chirurgicznych. W pracy opisano przypadek pacjentki, u której przeprowadzono zabiegi osteogingiwoplastyki i frenulotomii, wykorzystujac $w$ trakcie gojenia miękko-twarda ptytke chirurgiczna wykonana $w$ technice termoformowania.
} 


\section{Introduction}

Preparation of the oral cavity of a patient undergoing a prosthetic treatment is an obligatory procedure in the daily practice of a dentist. The most frequently performed procedures include basic periodontal treatments (scaling, curettage), activities in the field of conservative dentistry (elimination of active cariouss lesions, endodontic treatment) or oral surgery, such as tooth extraction, elimination of pathology within hard and soft tissues or improvement of the quality of prosthetic area. ${ }^{1-5}$ Appropriate preparation of the patient's oral cavity ensures an effective, long-term rehabilitation of the stomatognathic system. Depending on the prosthetic treatment plan, it is sometimes necessary to prepare additional tools routinely used by a specialist of another field of dentistry. An example of such tools is surgical templates, also called surgical plates. ${ }^{6}$ They are designed to maintain and properly shape the healing structures that will postoperatively become the future prosthetic area. The routine treatment used by clinicians consists of the use of surgical templates made of polymethylmethacrylate (heat-curing flasking or self-curing materials for the production of individual impression trays), based on properly prepared plaster models. The development of materials' science at the turn of the last decades, and the improvement of devices used in prosthetic laboratories, make it possible not only to search for technologically superior solutions, but also to accelerate the laboratory performance of specific prosthetic constructions. Thermoforming is a recognized method used in dental technology laboratories. It involves shaping plastics heated to the right temperature. On the market there are various types of devices that can be divided into two main groups, which are based either on underpressure shaping or vacuum shaping. The thermoforming technique allows creation of i.e.: orthodontic appliances, retainers, surgical

\section{Wstęp}

Przygotowanie jamy ustnej do rozpoczęcia leczenia protetycznego jest obowiązującym postępowaniem w codziennej praktyce lekarza dentysty. Najczęściej wykonywanymi zabiegami są podstawowe zabiegi periodontologiczne (usunięcie kamienia nazębnego, kiretaż), czynności z zakresu stomatologii zachowawczej (wyeliminowanie ognisk aktywnej próchnicy, leczenie endodontyczne) czy chirurgii stomatologicznej, takie jak usunięcie zębów, eliminacja patologii w obrębie twardych i miękkich tkanek czy polepszenie jakości pola protetycznego. ${ }^{1-5}$ Odpowiednie przygotowanie jamy ustnej pacjenta otwiera możliwości skutecznej i długotrwałej rehabilitacji układu stomatognatycznego. W zależności od planu leczenia protetycznego niekiedy konieczne jest przygotowanie dodatkowych narzędzi wykorzystywanych przez lekarza z zakresu innej dziedziny stomatologii. Przykładem takich dodatkowych aparatów są szablony chirurgiczne nazywane również płytkami chirurgicznymi. ${ }^{6}$ Są to aparaty mające za zadanie odpowiednie utrzymanie oraz formowanie gojących się struktur, które stanowić będą przyszłe podłoże protetyczne po przeprowadzonym zabiegu chirurgicznym. Rutynowym postępowaniem wykorzystywanym przez klinicystów jest stosowanie szablonów chirurgicznych wykonywanych z polimetakrylanu metylu (polimeryzowanego „na gorąco" metodą puszkowania lub z samopolimeryzujących tworzyw przeznaczonych do produkcji łyżek indywidualnych), na podstawie odpowiednio przygotowanych modeli gipsowych. ${ }^{7}$ Rozwój materiałoznawstwa na przełomie ostatnich dziesięcioleci oraz udoskonalenie urządzeń wykorzystywanych w laboratoriach protetycznych umożliwia poszukiwanie nie tylko lepszych pod względem technologicznym rozwiązań, ale również przyspiesza wykonawstwo laboratoryjne określonych konstrukcji protetycznych. Metoda termoformowania jest ogólnie uznaną metodą 
templates for implant procedures, relaxation splints, bleaching splints or various types of mouthguards for athletes. ${ }^{8-9}$ Thermoforming makes it possible to fabricate perfectly fitting devices, which reduces the risk of making an error at the same time shortening the time of their implementation. Upon placement in the oral cavity they have a very specific role to perform. The described clinical case concerns pre-prosthetic plastic surgery of the alveolar part of the mandible with the use of a surgical plate made with thermoforming technique.

\section{Case report}

A 51-year-old female patient presented at the Department of Prosthodontics to start prosthetic treatment. In medical history, the patient reported multiple sclerosis (Sclerosis multiplex), diagnosed 29 years earlier, treated with ocrelizumab infusions every six months. Difficult motor coordination associated with progressive systemic disease was observed. The dental examination revealed partial edentulism and tooth cavities, which classified patient's dentition in group B4 according to the Eichner classification (intermaxillary contact occurring away from occlusal supporting zones). Pathological tooth wear of teeth 3343 was also observed, particularly marked in the area of antagonistic metal-ceramic dental bridge based on teeth 11-13. The patient used an upper framework denture made about 15 years earlier. At the time of presenting for treatment, the patient was on day 3 after multiple tooth extractions (teeth 14, 15, 16, 17, 34, 44) (Fig. 1). The next visit was postponed until the soft tissues completely healed. After four weeks, impressions of alginate mass (Kromopan, Lascod Italy) were taken on standard impression trays for diagnostic models and the patient was referred to the Department of Conservative Dentistry to eliminate caries from the oral cavity. The prosthetic treatment wykorzystywaną w pracowniach techniki dentystycznej. Termoformowanie polega na kształtowaniu nagrzanych do odpowiedniej temperatury tworzyw sztucznych. Na rynku dostępne są różnego rodzaju urządzenia, które można podzielić na dwie główne grupy: wykorzystujące kształtowanie pod ciśnieniem lub kształtowanie próżniowe. Tak zwaną techniką formowania wgłębnego wykonane mogą być między innymi: aparaty ortodontyczne, retainery, szablony implantologiczne, szyny relaksacyjne, nakładki wybielające czy różnego rodzaju szyny ochronne dla sportowców. ${ }^{8-9}$ Termoformowanie pozwala na wytworzenie dokładnie dopasowanych prac, co zmniejsza ryzyko popełnienia błędu jednocześnie skracając czas ich wykonania, a które wprowadzone do jamy ustnej mają do spełnienia konkretne zadania. Opisany przypadek kliniczny dotyczy przedprotetycznego zabiegu plastyki części zębodołowej żuchwy z wykorzystaniem płytki chirurgicznej wykonanej metodą formowania wgłębnego.

\section{Opis przypadku}

Pacjentka w wieku 51 lat zgłosiła się na konsultację, w celu rozpoczęcia leczenia protetycznego. W wywiadzie ogólnym pacjentka podała stwardnienie rozsiane (Sclerosis multiplex), zdiagnozowane 29 lat temu, leczone infuzjami okrelizumabu co 6 miesięcy. Zaobserwowano utrudnioną koordynację ruchową związaną $\mathrm{z}$ postępującą chorobą ogólnoustrojową. Badanie stomatologiczne wykazało braki ilościowe i jakościowe uzębienia, sklasyfikowane w grupie B4 według klasyfikacji Eichnera (kontakty przeciwstawne występujące poza strefami podparcia). Starcie patologiczne zębów 33-43, w szczególności zaznaczone w obszarze obecności przeciwstawnego mostu porcelanowego na podbudowie metalowej opartego na zębach 11-13. Pacjentka użytkowała górną protezę szkieletową wykonaną około 15 lat wcześniej. W momencie zgłoszenia się do leczenia 


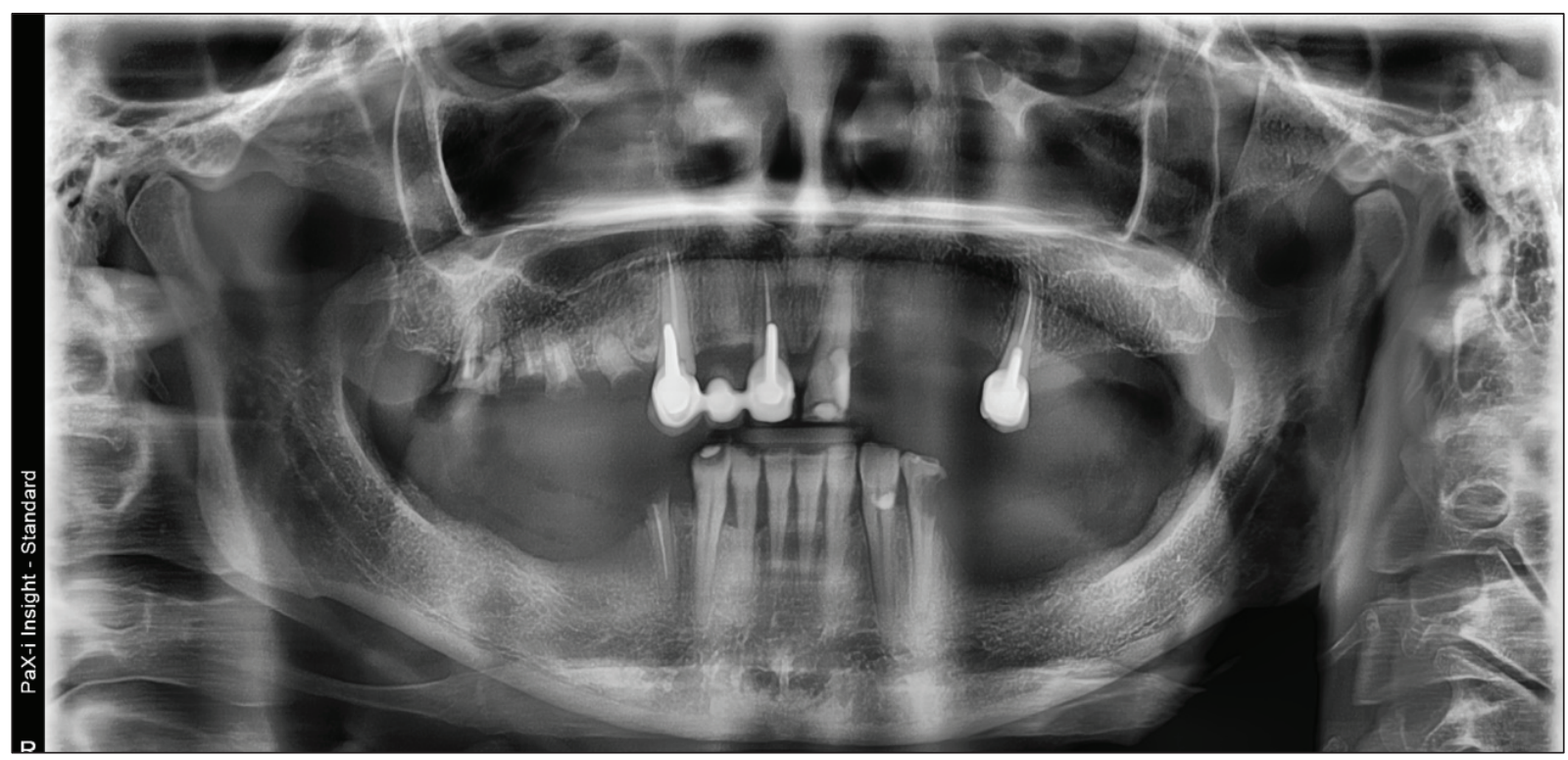

Fig. 1. OPG before the teeth extraction procedure.

Ryc. 1. Zdjęcie pantomograficzne wykonane przed zabiegiem usunięcia zębów.

plan accepted by the patient involved the performance of two acrylic resin removable partial dentures and composite reconstruction of the pathologically worn down incisal edges of the lower teeth. Subsequent intraoral studies and model analysis indicated the need to perform pre-prosthetic oral surgery in the area of the extracted tooth 44 due to the sharp bone margin of the alveolar part of the mandible (Fig. 2). A sharp, confined bone unevenness in the shape of a spike covered with a thin, stretched mucous membrane was responsible for tenderness in this area. Retraction of the cheeks also revealed high location of the frenal attachments and the significant shortening of the oral vestibular depth in the area of the extracted tooth 34 (Fig. 3). The surgery was necessary due to the anticipated difficulties in proper stabilization and retention of the lower partial denture.

In order to create a surgical template, duplicated diagnostic models were appropriately prepared - the undercuts were blocked and the basis of the plaster model was processed in a way allowing the free flow of air sucked in pacjentka była w 3 dobie po mnogich ekstrakcjach (usunięte zęby 14, 15, 16, 17, 34, 44) (ryc. 1). Kolejną wizytę odroczono do czasu całkowitego wygojenia się tkanek miękkich. Po 4 tygodniach pobrano wyciski masą alginatową (Kromopan, Lascod Italy) na standardowych łyżkach wyciskowych w celu wykonania modeli diagnostycznych oraz skierowano pacjentkę do Zakładu Stomatologii Zachowawczej w celu wyeliminowania ognisk próchnicy z jamy ustnej. Zaakceptowany przez pacjentkę plan leczenia protetycznego zakładał wykonanie dwóch protez częściowych osiadających oraz odbudowę kompozytową patologicznie startych brzegów siecznych zębów dolnych. Kolejne badania wewnątrzustne oraz analiza modeli wskazała na konieczność przeprowadzenia zabiegów przedprotetycznego chirurgicznego przygotowania jamy ustnej w okolicy usuniętego zęba 44 z powodu ostrego brzegu kostnego części zębodołowej żuchwy (ryc. 2). Ostra, ograniczona nierówność kostna o kształcie kolca pokryta cienką, napiętą błoną śluzową była powodem tkliwości tej okolicy. Retrakcja policzków uwidoczniła również wysokie umiejscowienie przyczepów więzadeł 


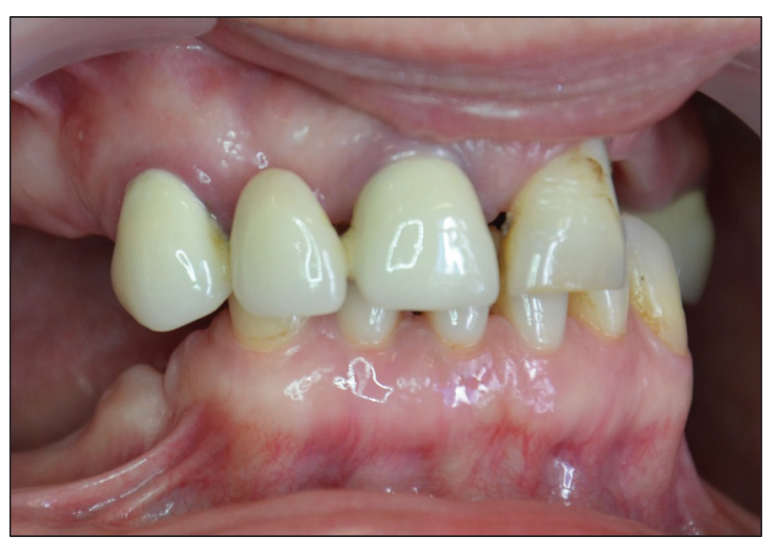

Fig. 2. Intraoral photograph - sharp bone margin in the area of extracted tooth 44.

Ryc. 2. Zdjęcię wewnatrzustne - ostry brzeg kostny w okolicy usuniętego zęba 44.

during the vacuum thermoforming process. In the described clinical case, the Erkoloc - Pro 3.0 thermoformable plates (Erkodent, Germany) were used to make the surgical plate. ErkolocPro 3.0 is a double-layer soft-hard plate made of polyethylene terephthalate glycol (PETG) and thermoplastic polyurethane (TPU). According to the manufacturer, the external hard layer (PETG) is easy to prepare and has the function of maintaining shape, while the soft layer (TPU) with increased elasticity, which is the intaglio side of the surgical plate, improves adhesion and facilitates adaptation to the oral mucosa. The compression molding process was carried out using the Erkoform 3D vacuum unit (Erkodent, Germany) in the dental technician laboratory. Mechanical preparation of the surgical plate and special holes were made to allow the template to be sewn into the oral cavity during the surgery. The plate prepared in this way was immersed in the disinfecting liquid.

\section{Description of the surgical procedure}

Due to the prominent additional buccal frenum around the first premolar in the mandible on the left side and the uneven alveolar part of

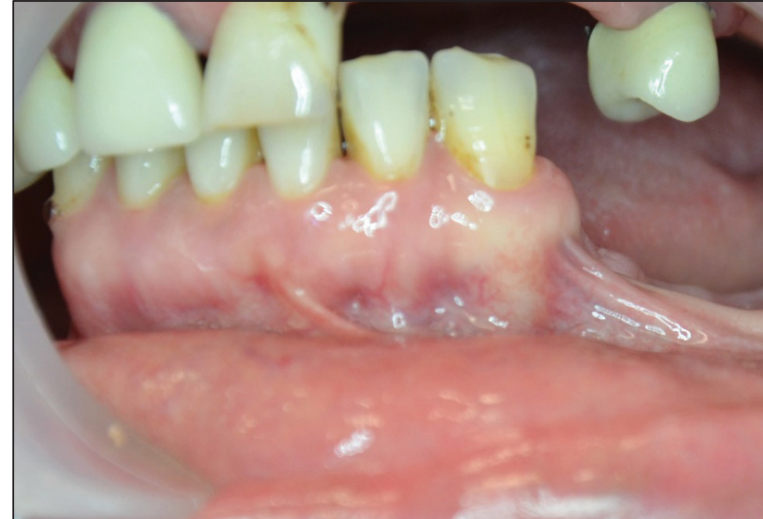

Fig. 3. Intraoral photograph - high placement of the buccal phrenum attachment around the extracted tooth 34.

Ryc. 3. Zdjęcie wewnatrzustne - wysokie umiejscowienie przyczepów więzadet policzka w okolicy usuniętego zęba 34 .

oraz znaczne spłycenie przedsionka jamy ustnej w okolicy usuniętego zęba 34 (ryc. 3). Opisane zabiegi były konieczne ze względu na przewidywane trudności w odpowiedniej stabilizacji i retencji protezy częściowej osiadającej dolnej.

W celu wykonania szablonu chirurgicznego, powielone modele diagnostyczne zostały odpowiednio przygotowane - zablokowano podcienie oraz opracowano cokół modelu gipsowego w sposób umożliwiający swobodny przepływ powietrza zasysanego $\mathrm{w}$ trakcie procesu termoformowania podciśnieniowego. W opisanym przypadku do wykonania płytki chirurgicznej wykorzystano termoformowalne folie Erkoloc - Pro 3,0 (Erkodent, Niemcy). Erkoloc-Pro 3,0 to dwuwarstwowa miękko-twarda płyta wykonana z polietylenu tetraftalatu-glikolu (PETG) oraz z termoplastycznego poliuretanu (TPU). Jak podaje producent zewnętrzna twarda warstwa (PETG) jest łatwa w obróbce mechanicznej oraz ma za zadanie utrzymanie kształtu, natomiast miękka warstwa (TPU), o zwiększonym module elastyczności, jest stroną dośluzową i polepsza przyleganie oraz ułatwia adaptację do błony śluzowej jamy ustnej. Proces tłoczenia wgłębnego został wykonany przy pomocy urządzenia podciśnieniowego Erkoform 3D 


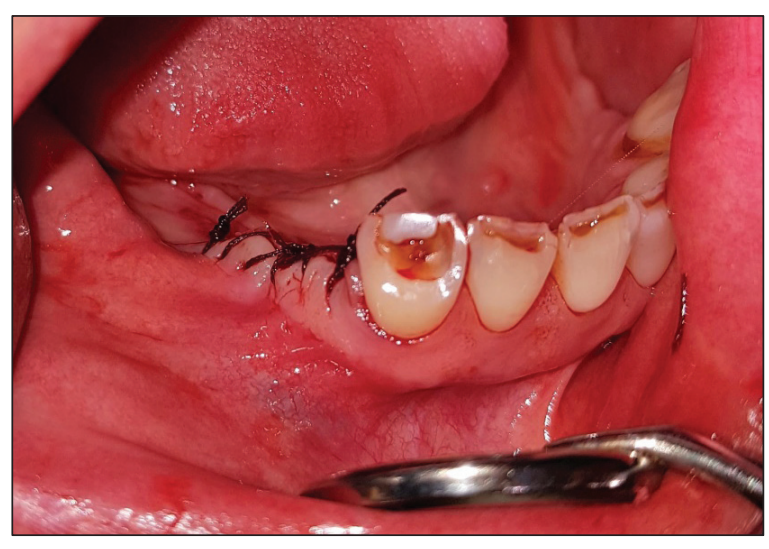

Fig. 4. Intraoral, intraoperative photograph-sutured wound after osteo-gingivoplasty.

Ryc. 4. Zdjęcie wewnątrzustne, śródzabiegowe - rana zaopatrzona szwami po zabiegu osteogingiwoplastyki.

the mandible on the right side, it was decided to perform frenulotomy on the left side and osteo-gingivoplasty on the right side. Since the patient suffered from multiple sclerosis and was on chronic oral steroids medication, it was necessary to prescribe antibiotic cover Augmentin $1.0 \mathrm{~g}$, every 12 hours for 7 days. Under local anesthesia, 2\% lignocaine with norepinephrine (3 ampoules), trapezoidal fullthickness flap was prepared on the right side. Using a round bone cutter on the surgical handpiece a correction of bone shape was made, then excess gingival tissue was removed, after which the wound was closed with surgical sutures (USP 3-0), multifilament (Fig. 4). Then frenulotomy was performed on the left side. An incision was made on the mucous membrane of the vestibule in the region of teeth 33-34. The partial-thickness flap was made and reflected gingivally, sliding and cutting the frenulum fibers. The partial-thickness flap was stabilized apically with sutures (USP 3-0). In order to avoid adhesions and vestibule shallowing after surgical procedures, a surgical template was placed for a period of two weeks and fixed to the mucosa on both sides with sutures (Fig. 5, 6).
(Erkodent, Niemcy) w laboratorium techniki dentystycznej. Wykonano obróbkę mechaniczną otrzymanej płytki chirurgicznej oraz specjalne nawierty w celu umożliwienia wszycia szablonu w jamie ustnej po przeprowadzonym zabiegu chirurgicznym. Tak przygotowana płytka umieszczona została w płynie dezynfekcyjnym.

\section{Opis zabiegu chirurgicznego}

W związku z wydatnym dodatkowym wędzidełkiem w okolicy pierwszego zęba przedtrzonowego w żuchwie po stronie lewej oraz nierówną częścią zębodołową żuchwy po stronie prawej, zdecydowano o konieczności wykonania frenulotomii po stronie lewej oraz osteogingivoplastyki po stronie prawej. Ze względu na chorobę pacjentki - stwardnienie rozsiane oraz przewlekłe doustne przyjmowanie leków sterydowych, zabieg wykonano w osłonie antybiotykowej, Augmentin 1,0 g, co 12 godzin przez 7 dni. W znieczuleniu nasiękowym 2\% lignokaina z noradrenaliną (3 ampułki), nacięto i odwarstwiono kopertowy płat śluzówkowo-okostnowy po stronie prawej oraz przy pomocy wiertła różyczkowego na prostnicę chirurgiczną wykonano korektę kształtu kości, a następnie usunięto nadmiary dziąsła, po czym ranę zszyto nicią o rozmiarze 3-0, multifilament (ryc. 4). Następnie wykonano frenulotomię po stronie lewej. Na błonie śluzowej przedsionka w okolicy zębów 33-34 poprowadzono cięcie, wypreparowano płat śluzówkowy i odwarstwiono go w kierunku dziąsła, zsuwając i wycinając przyczep wędzidełka. Założono szwy o rozmiarze 3-0 stabilizując płat częściowy w kierunku dowierzchołkowym. W celu uniknięcia wystąpienia zrostów oraz spłycenia przedsionka po zabiegach chirurgicznych, założono szynę chirurgiczną na okres 2 tygodni, przymocowując ją obustronnie szwami pojedynczymi do błony śluzowej (ryc. 5, 6). Wizytę kontrolną przeprowadzono po 1 dniu od usunięcia płytki chirurgicznej (ryc. 7, 8). 


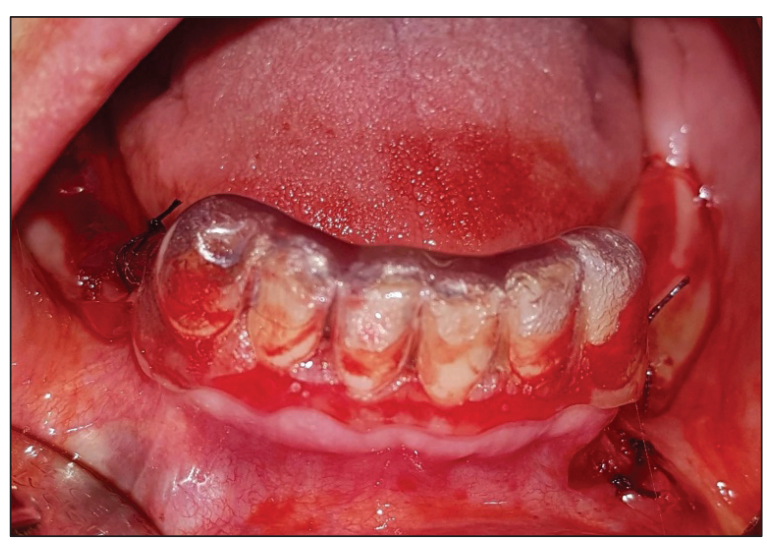

Fig. 5. Intraoral, intraoperative photograph - state after stabilization of the surgical template to the mucosa with single sutures.

Ryc. 5. Zdjęcie wewnatrzustne, śródzabiegowe - stan po ustabilizowaniu szablonu chirurgicznego do błony śluzowej pojedynczymi szwami.

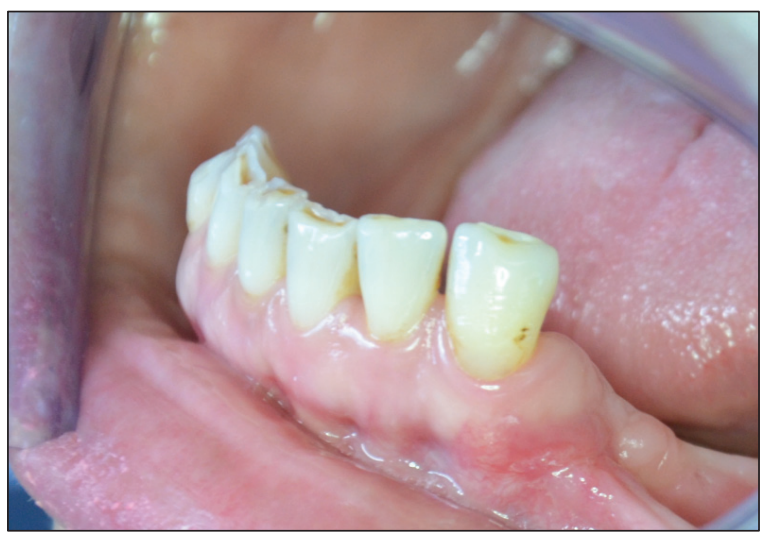

Fig. 7. Intraoral photograph - 1 day after removal of surgical plate, left side.

Ryc. 7. Zdjęcie wewnatrzustne po 1 dniu od usunięcia ptytki chirurgicznej, strona lewa.

\section{Discussion}

Although the use of surgical plates is not a novel method, it is still rarelyused. The possibility of creating additional retention for prosthetic restorations by means of dental implants and choosing proper implant connectors has become without question a great convenience. ${ }^{10-13}$ In some cases, this makes alveolo- and gingivoplasty unnecessary. ${ }^{1}$ However, the implantoprosthetic treatment is not possible in

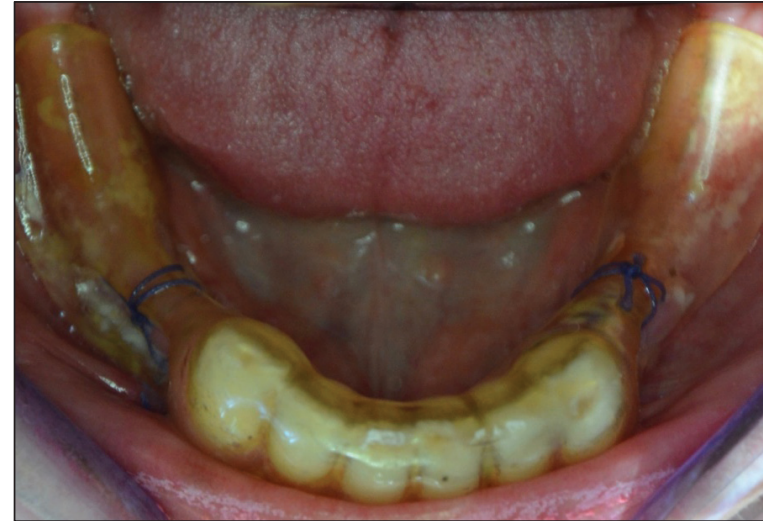

Fig. 6. Intraoral photograph-14 days after performer procedure.

Ryc. 6. Zdjęcie wewnatrzustne - stan po 14 dniach od wykonanego zabiegu.

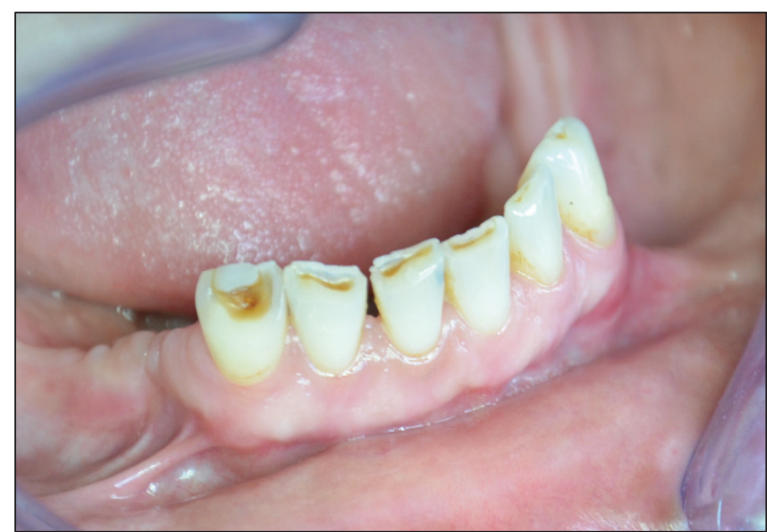

Fig. 8. Intraoral photograph - 1 day after removal of surgical plate, right side.

Ryc. 8. Zdjęcie wewnątrzustne po 1 dniu od usunięcia plytki chirurgicznej, strona prawa.

\section{Dyskusja}

Wykorzystanie płytek chirurgicznych nie jest metodą nową, jednak nadal rzadko stosowaną. Możliwości stworzenia dodatkowej retencji uzupełnienia protetycznego przy użyciu zabiegów implantologicznych oraz dobrania odpowiednich łączników jest w ostatnich latach niewątpliwym udogodnieniem. ${ }^{10-13}$ Ogranicza to konieczność wykonywania zabiegów z zakresu osteo- czy gingiwoplastyki. ${ }^{1}$ Jednak nie 
every case. ${ }^{14-16}$ Moreover, implant connectors can be hard to clean properly, especially by elderly people or patients with impaired motor coordination, ${ }^{17,18}$ like in the presented case. A correctly shaped and executed surgical template accompanied by a properly done surgery can determine the success of the treatment carried out by an interdisciplinary team consisting of a prosthodontist and a dental surgeon. Due to the multitude of solutions, the selection of the right material for the implementation of surgical plates can cause problems. The thermoforming technique, which was presented in this case, is very fast and easy to perform and shows stable parameters over time. ${ }^{19}$ Dhima et al. pay attention to the inconvenience of embedding and removing the template, in particular when the residual teeth have a significant degree of mobility. ${ }^{20}$ The authors of this study believe that a proper blocking of undercuts on a plaster model, and susceptibility of intaglio surface of a soft-hard surgical plate (impossible to obtain using flasking technique or quick self-curing materials), can eliminate these disadvantages. Templates made in 3-D printing technology, which are more and more commonly used as surgical templates during implantation procedures, seem to be an alternative in such cases but apart from specialist devices this method also requires, appropriate software and trained personnel in this field.

\section{Conclusions}

The soft-hard surgical plate made with thermoforming techniques should be commonly used in the pre-prosthetic surgery. The possibility of using two different types of materials' hardness allows, firstly, obtaining the appropriate rigidity of the template, enabling performance of the surgical procedure and, secondly, a good adaptation to the surface of the teeth, gum and mucous membrane to provide comfort to the patient during the healing w każdym przypadku możliwa jest implantoprotetyczna metoda leczenia. ${ }^{14-16}$ Ponadto łączniki mogą być trudne w oczyszczaniu, szczególnie u osób $\mathrm{w}$ podeszłym wieku czy z upośledzoną koordynacją ruchową ${ }^{17,18}$ - tak jak to miało miejsce u pacjentki opisanej powyżej. Odpowiednie ukształtowanie i wykonanie szablonu chirurgicznego w połączeniu z właściwie przeprowadzonym zabiegiem może przesądzić o sukcesie leczenia zrealizowanym w interdyscyplinarnym zespole składającym się z lekarza protetyka i chirurga stomatologicznego. Dobór odpowiedniego materiału do wykonania płytek chirurgicznych ze względu na mnogość rozwiązań może przysporzyć problemów. W opisanym przypadku wykorzystano metodę termoformowania, która jest metodą szybką i bardzo prostą do wykonania, o niezmiennych parametrach w czasie. ${ }^{19}$ Dhima i wsp. zwracają uwagę na niedogodności związane z osadzeniem oraz zdejmowaniem szablonu w szczególności, gdy zęby rezydualne są o znacznym stopniu ruchomości. ${ }^{20}$ Autorzy niniejszej pracy uważają, że odpowiednie zablokowanie podcieni na modelu roboczym oraz fakt pewnej podatności strony dośluzowej w płytce miękko-twardej (niemożliwej do uzyskania przy wykorzystaniu akrylu polimeryzowanego metodą puszkowania lub materiałów szybkopolimeryzujących) może eliminować te niedogodności. Alternatywnym rozwiązaniem w takich przypadkach wydają się szablony wykonywane w technologii druku 3D, które coraz częściej wykorzystywane są jako szablony chirurgiczne przy zabiegach implantacji, jednak metoda ta wymaga oprócz specjalistycznych urządzeń również odpowiedniego oprogramowania i wyszkolonego w tym kierunku personelu.

\section{Podsumowanie}

Zastosowanie płytki miękko-twardej wykonanej metodą termoformowania znajduje swoje miejsce w chirurgii przedprotetycznej. 
period. Despite the implementation of more and more modern techniques of both prosthetic treatment and designing templates using digital devices and computed tomography, it is worth considering a thermoformable soft-hard plate, which is not only an easy and quick method, but also cheap and widely available.
Zastosowanie dwóch rodzajów twardości materiału pozwala zarówno na uzyskanie odpowiedniej sztywności szablonu, dzięki czemu możliwe jest prawidłowe przeprowadzenie zabiegu chirurgicznego, jak i pewnej swobody w dopasowaniu go do powierzchni zębów, dziąsła i błony śluzowej, a także zapewnienie komfortu pacjentowi w trakcie okresu gojenia. Mimo wdrażania coraz nowocześniejszych technik zarówno leczenia protetycznego, jak i projektowania szablonów przy pomocy urządzeń cyfrowych oraz tomografii komputerowej wiązką stożkową, warto mieć na uwadze możliwość zastosowania termoformowalnej płytki miękko-twardej, która jest metodą łatwą i szybką w wykonaniu, a także tanią i powszechnie dostępną.

\section{References / Piśmiennictwo}

1. Hillerup $S$ : Preprosthetic surgery in the elderly. J Prosthet Dent 1994; 72(5): 551-558.

2. Devaki VN, Balu K, Ramesh SB, Arvind RJ, Venkatesan: Pre-prosthetic surgery: Mandible. J Pharm Bioallied Sci 2012; 4(Suppl 2): S414416.

3. Hopkins R, Stafford GD: Experience of preprosthetic surgery on the atrophic endentulous mandible. Br Dent J 1974; 137(9): 341-346.

4. Hopkins R, Stafford GD, Gregory MC: Preprosthetic surgery of the edentulous mandible. Br Dent J 1980; 148(7): 183-188.

5. Hochstedler JL, Finger IM: Preprosthetic surgery. Gen Dent 1998; 46(6): 626-630.

6. Jung SR, Bashutski JD: A bone-level stabilized surgical template to manage enlarged nonrestorable maxillary tuberosities. J Prosthet Dent 2010; 103(5): 319-320.

7. Jagger $R G$, Okdeh A: Thermoforming polymethyl methacrylate. J Prosthet Dent 1995; 74(5): 542-545.

8. Gawlak D, Manka-Malara K, Kaminski T,
Luniewska M, Mierzwinska-Nastalska E: Comparative evaluation of custom and standard boil and bite (self-adapted) mouthguards and their effect on the functioning of the oral cavity. Dent Traumatol 2016; 32(5): 416-420.

9. Gawlak D, Mierzwinska-Nastalska E, MankaMalara K, Kaminski T: Comparison of usability properties of custom-made and standard self-adapted mouthguards. Dent Traumatol 2014; 30(4): 306-311.

10. Svetlize CA, Bodereau EF Jr: Comparative study of retentive anchor systems for overdentures. Quintessence Int 2004; 35(6): 443-448.

11. Batenburg RH, Meijer HJ, Raghoebar GM, Vissink A: Treatment concept for mandibular overdentures supported by endosseous implants: a literature review. Int J Oral Maxillofac Implants 1998; 13(4): 539-545.

12. Batenburg RH, Raghoebar GM, Van Oort RP, Heijdenrijk $K$, Boering $G$ : Mandibular overdentures supported by two 
or four endosteal implants. A prospective, comparative study. Int J Oral Maxillofac Surg 1998; 27(6): 435-439.

13. Visser A, Raghoebar GM, Meijer HJ, Batenburg RH, Vissink A. Mandibular overdentures supported by two or four endosseous implants. A 5-year prospective study. Clin Oral Implants Res 2005; 16(1): 19-25.

14. Moy PK, Medina D, Shetty V, Aghaloo TL: Dental implant failure rates and associated risk factors. Int $\mathrm{J}$ Oral Maxillofac Implants 2005; 20(4): 569-577.

15. Hwang $\quad D$, Wang $H L$ : Medical contraindications to implant therapy: Part II: Relative contraindications. Implant Dent 2007; 16(1): 13-23.

16. Holahan CM, Koka S, Kennel KA, Weaver $A L$, Assad DA, Regennitter FJ, et al.: Effect of osteoporotic status on the survival of titanium dental implants. Int J Oral Maxillofac Implants 2008; 23(5): 905-910.

17. Bergmann FDE: Nie zawsze technologia CAD/CAM jest konieczna. Imlantol Stomatol 2017; 8(1): 48-54.

18. Kiener P, Oetterli M, Mericske E, MericskeStern $R$. Effectiveness of maxillary overdentures supported by implants: maintenance and prosthetic complications. Int J Prosthodont 2001; 14(2): 133-140.

19. Jagger $R G$. Dimensional accuracy of thermoformed polymethyl methacrylate. J Prosthet Dent 1996; 76(6): 573-575.

20.Dhima M, Koka S, Rieck KL: A toothstabilized surgical template for alveolectomy. J Prosthet Dent 2013; 110(6): 529-531.

Zaakceptowano do druku: 26.09.2019 r.

Adres autorów: 02-097 Warszawa, ul. Binieckiego 6.

(C) Zarząd Główny PTS 2019. 